\title{
CHURCHES, GRAVES AND A GLASSMAKING WORKSHOP: MEDIEVAL AND EARLY MODERN PERIOD EXCAVATIONS BY THE 15-YEAR-OLD ÁSATÁRS LTD.
}

\section{Zsolt GaLLINA - GyöNGYi GuLYÁs}

Hungarian Archaeology Vol. 9 (2020), Issue 1, pp. 36-45, https://doi.org/10.36338/ha.2020.1.2

In the previous issue of the Hungarian Archaeology E-journal, we introduced three prehistoric sites that have been significant parts of our company's work for the last two years. In this essay, we also report on our work over the last few years, focusing on three significant medieval and Early Modern Period sites. These sites are important to us because they were planned systematic excavations that were supported in part by the National Cultural Fund of Hungary. The excavation at Garáb was sponsored by the owner of the land, which is remarkable.

\section{MEDIEVAL CHURCH AND CEMETERY AT GARÁB}

The church and monastery buildings of medieval Garáb (Grabensia, Gravia) in Nógrád County probably became the victims of construction work at the re-emerging village in the 18th century. Carved stones, which most probably came from the medieval church and monastery, can still be observed in the walls of the St. Aloysius Catholic church and in several houses standing there. The first excavation was carried out in 1987 by Katalin Bodnár and Tamás Maicher using surveying ditches. The aim of this excavation was to identify the exact site of the former monastery. The excavation revealed the remains of a church with a rectangular apse and what is assumed to be a monastery, as well as double walls that most probably surrounded the monastery and 14 graves around the church (BODNÁR 1988, 35-36).

Since the beginning of the 2000s, the new owner of the land, György Juhász, has shown great interest in the medieval history of Garáb, and therefore he has supported the research into the former church and monastery. His long-term goal is to reconstruct the walls of the church as high as possible and exhibit it. As a result, a planned excavation started in 2018 with the aim of completely excavating the medieval church in addition to wall sections that were visible in a geophysical survey carried out in 2017 . We also excavated a small part of the late medieval settlement and parts of a cemetery surrounding the church that contained several hundred graves (Fig. 1). As a result, it was possible to determine the northwestern edge of the cemetery.

In 2018/2019 almost 500 features, including almost 400 graves/skeletal remains, and medieval and Early Modern Period settlement features were documented. The most significant feature of the excavation was a church almost in the shape of a Greek cross. The church had a central structure, was built in the 11th-12th centuries, had a length of 14.7 $\mathrm{m}$, a width of $12 \mathrm{~m}$, and was oriented in an east-west direction (Fig. 2). The western transept is longer

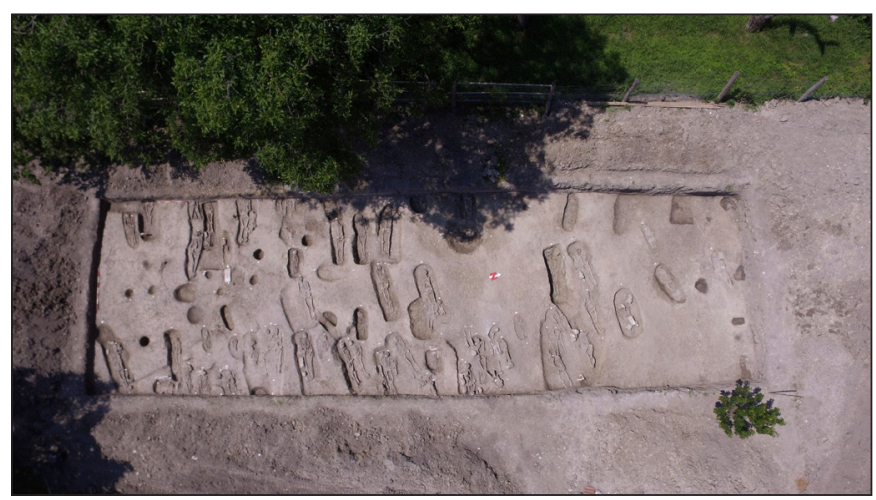

Fig. 1. Part of the churchyard at Garáb in an aerial photograph (Photograph: Máté Kurucz and Péter Czukor)

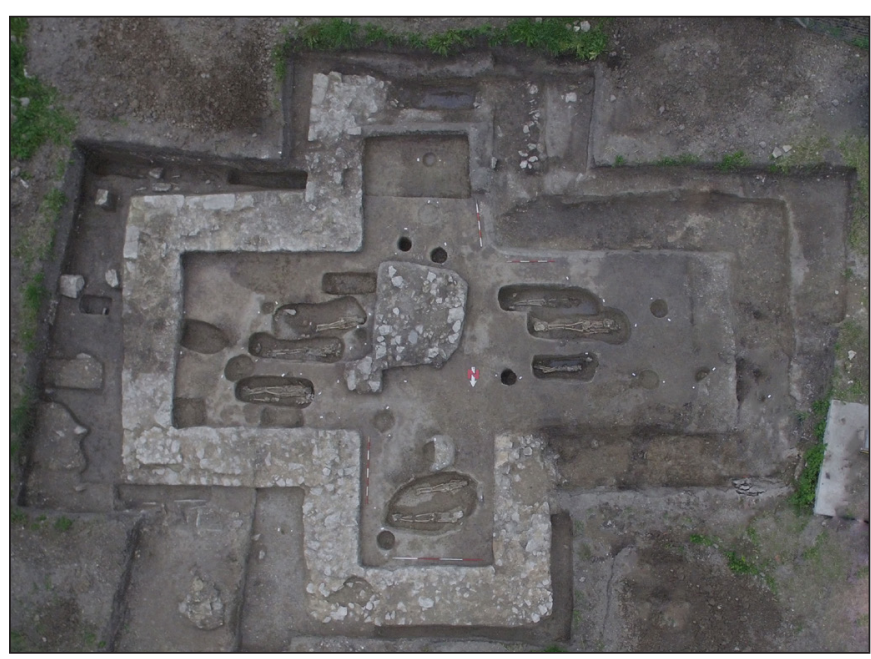

Fig. 2. Aerial photograph of the church shaped like a Greek cross at Garáb (Photograph: Máté Kurucz) 
than the rectangular-shaped sanctuary by only $1.4 \mathrm{~m}$. The northern and southern transepts are stockier but they are identical, with widths of 390-420 cm and lengths of 530-540 cm. The wall of the church could be observed throughout the entire apse, in the northern transept and in the southwestern part of the southern transept. In other places, only the remains of foundation ditches were found. The so-called pouring technique could clearly be observed; along the wall, 30-35 cm large rectangular stones were laid and the area between the wall and the area between the stones was filled in with gravel and mortar. The interior debris has mostly survived to a higher level since it was mainly the exterior ashlar stones that were removed. The width of the wall varies between 125 and $135 \mathrm{~cm}$, while the emptied foundation trench is 120-140 cm wide. Both inside and outside of the church we reached the former walking surface. Inside the church and outside, close to the wall, we excavated several rounded postholes. According to the differences in their infill, they were probably not dug at the same time and they most probably indicate the different construction periods of the church. Inside the church, we found the scattered remains of a terrazzo floor.

In the immediate surroundings of the church, at a depth of 30-35 cm below the topsoil as well as in the graded debris down to the subsoil (at a depth of 1-2 m), we excavated several hundred burials. After removing the debris, we found several cover stones north of the church, which were in secondary positions but more or less in the same layer and close to one another. The skeletons were oriented approximately in a W-E direction and they were laid on their back in a supine position. The arms were laid along the body or were bent and laid on the belly or on the pelvis. In one or two cases, arms were bent to the chin. In several graves, we found signs of former coffins, including wood remains, a greyish brown patch in the layer where the grave appeared in the subsoil or on the bottom of the grave, and coffin nails. We observed charcoal remains at the bottom of some Árpád Period graves or on the skeletons. Signs of burning in the graves appear in the 12th century, possibly as a result of southern influences. This is probably not a pagan custom, and it is conceivable that it was a symbol of purgatory (Szabolcs Rosta, personal communication). In some cases, the arms were so close to the body that the use of a burial shroud can be assumed. We found hardly any grave goods. In two graves, obols were placed in the mouths, and we also found simple open large bracelets, hair rings with S-shaped ends, simple band finger rings, and in one case a glass bead and one silver signet ring. One iron belt buckle was also discovered as a scattered find (Fig. 3).

Almost 30 skeletons show irregularities, which can be divided into two groups: dead who were originally buried irregularly, and bodies that were disturbed later. In the first group, skeletons appear in a crouched position or placed with the face down (one skeleton facing down was also found inside the church). In the second group, skeletons were disturbed years after the burial. Their femurs or their entire legs were turned by $180^{\circ}$ and the skull or the upper part of the skeleton was disturbed (Fig. 4). These practices always took place in graves with coffins and the position of the bones was changed within the coffins. The graves still must have been visible at that time in order to manipulate the corpse. Changing the position of the femurs or the whole leg could only have been possible when the body had decomposed, since there are no signs of cut marks. Therefore, these practices

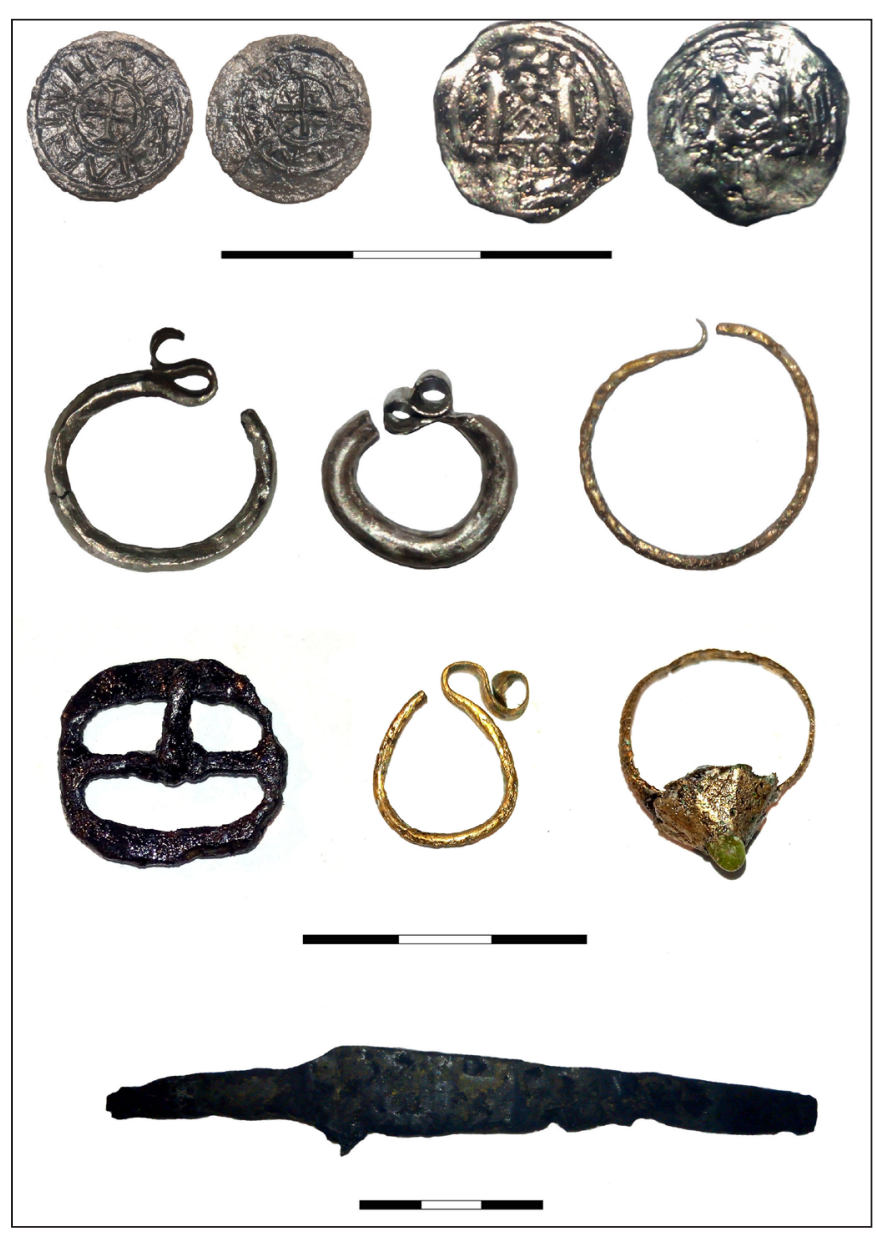

Fig. 3. Metal finds from Garáb (Photographs: Gyöngyi Gulyás and Gábor Barta) 
Zsolt Gallina - Gyöngyi Gulyás • Churches, Graves and a Glassmaking Workshop

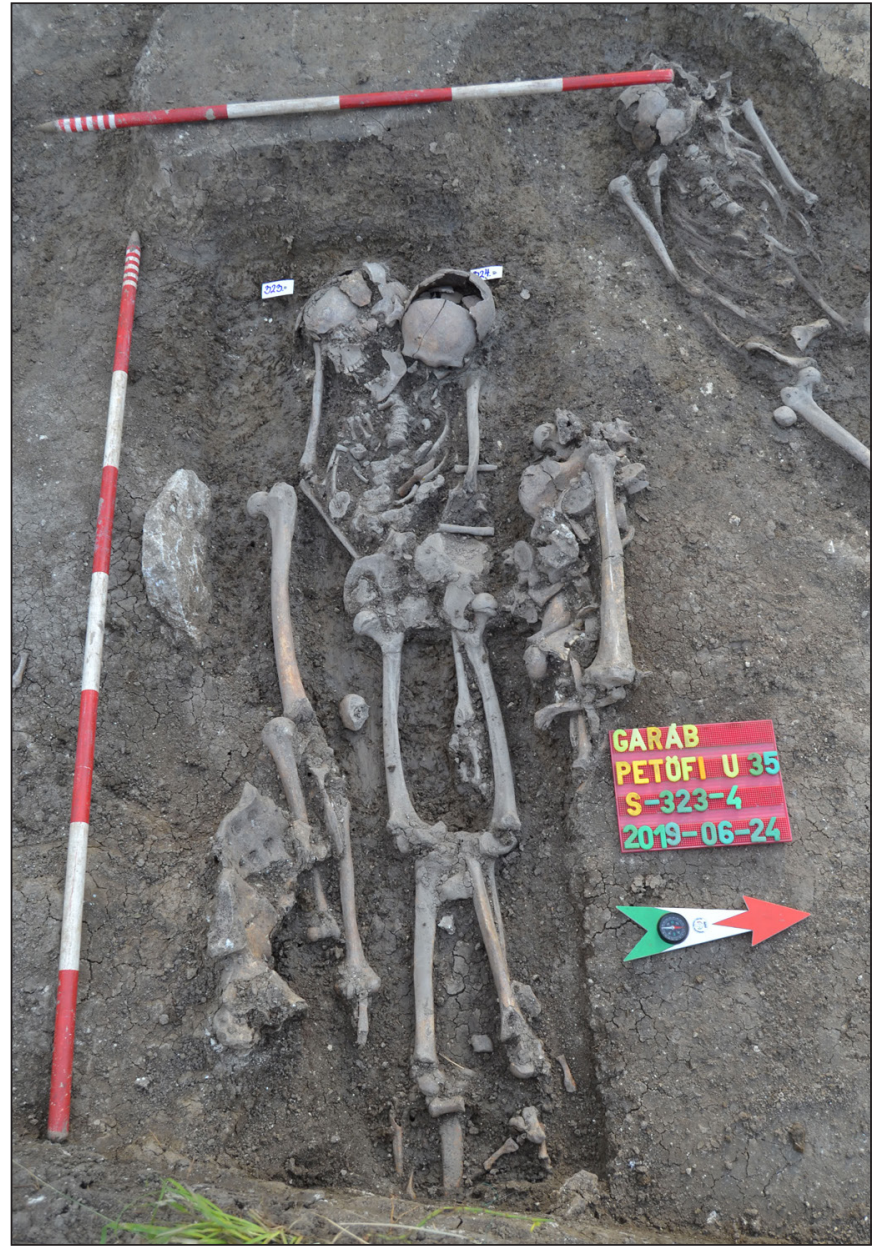

Fig. 4. A disturbed grave at Garáb (Photograph: Gyöngyi Gulyás)

took place several years after the burial, but no more than three or four decades later. The reasons for such practices are difficult to determine, only hypotheses can be made. They are most probably local variants of the fear of the dead coming back to life, or are the result of the arrival of a new population (?). In this latter case, a series of abuses to the local community can be supposed to be behind the practices. Two of these graves had finds that could be used for dating the graves; these were silver denarii of Koloman the Learned (1095-1116), which were placed in the mouths of the dead.

According to these denarii, prior to the establishment of a Premonstratensian monastery (1179) in Garáb, there had been an earlier church and cemetery. It is still unknown whether this church later became the property of the Premonstratensian Order. The architecture of the church is certainly foreign, and we also know of another cemetery close to the modern church, no more than $200 \mathrm{~m}$ away. Perhaps that is the place where the church of the Premonstratensian Order existed. Our long-term plan is to completely excavate and reconstruct the earlier church and Premonstratensian monastery.

In 1436, the convent died out and its properties went to the monastery of Ipolyság, then in 1688 the Jesuits at Besztercebánya (Banská Bystrica, Slovakia) received it and built the predecessor of the modern church. The walls of the former Premonstratensian monastery were still standing in 1797, and stones from it were used by the locals when the village was rebuilt (BODNÁR 1988, 36-36).

\section{A HUNGARIAN CONQUEST PERIOD GRAVE, A MEDIEVAL VILLAGE, A CEMETERY AND CHURCHES AT TÁZLÁR-TEMPLOMHEGY}

In Tázlár (Bács-Kiskun County), there have been test, rescue and systematic planned excavations since 2003. By 2019 , more than $7,000 \mathrm{~m}^{2}$ of the 40-hectare site had been excavated. Among the 1044 excavated features, 580 belong to the Árpád and medieval periods, such as graves/skeletons, two churches, a tripartite ditch and a few hundred medieval settlement features.

Tázlár is situated in the heart of the Great Hungarian Plain, in the Homokhátság Region, within in the triangle made by Kiskunhalas, Kiskunmajsa and Soltvadkert. The archaeological site is one of the best known in this area, and is traditionally referred to as 'Church Hill' by locals that still recall the old days. Unfortunately, the condition of the site has deteriorated continuously in the last few decades due to agricultural work, looting and earth removal.

One of the most important finds is the grave of a high-ranking woman from the Hungarian Conquest Period (around the middle of the 10th century) (for more details on the grave see GULYÁs, GALLINA \& TÜRK 2019, 115-121). The grave was oriented in a WNW-ESE direction and was rectangular shaped, in which a female skeleton in a supine position was found. This Europo-Mongoloid (Turanid) type woman was over 50 years old at death and her skeleton was well preserved. ${ }^{1}$ The skeleton was pushed slightly towards the

The skeleton was analysed by Antónia Marcsik. 

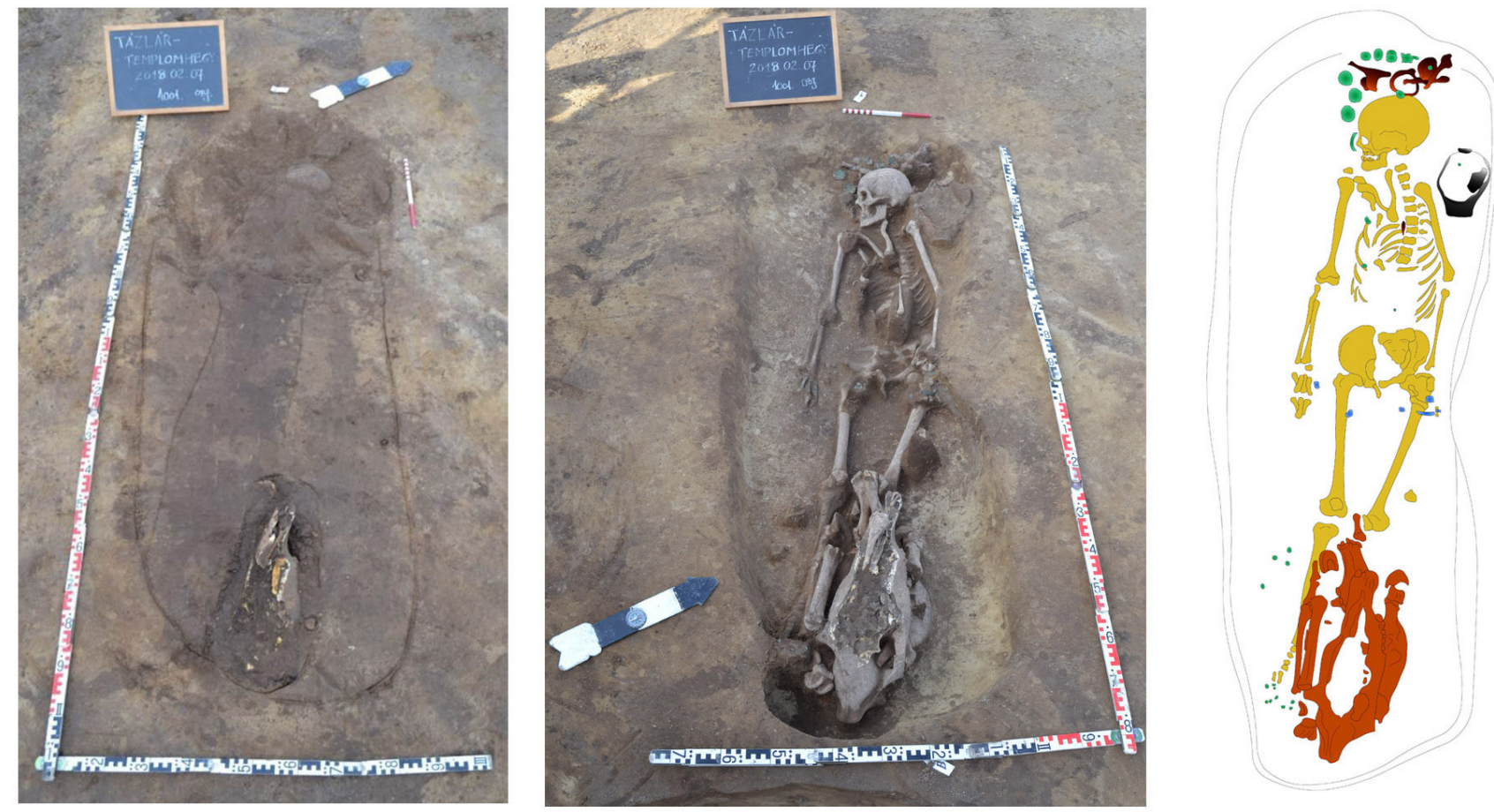

Fig. 5. Hungarian Conquest Period grave from Tázlár-Templomhegy: photograph of the discoloration of the grave on the surface, photograph and drawing of the excavated grave (Photographs: Gyöngyi Gulyás, drawing: Zsolt Gallina, GIS: Archeoline Ltd.)

northern side of the grave, so perhaps the grave originally had a sidewall niche. A partial horse burial, without skin, was discovered in front of and above her feet (Fig. 5). This burial custom is common in the western part of the Maros River estuary, with the roots of this custom having been brought by the Hungarians from the east. There were 94 grave goods in the grave (Fig. 6). Along with two silver bracelets on the chest and stomach area, her dress was closed in this area with small bronze ball buttons. The lowest part of the dress and the wrist sections were decorated with narrow, thin silver sheets. On her left arm, she had a silver band bracelet, on her finger a silver band ring, and there was an iron awl on her chest. The upper parts of her shoes were decorated with more than 60 small semi-spherical silver mounts. There was a saddle and horse tack placed below her head, including small, asymmetric pear-shaped iron stirrups and a horse bit with cheek-pieces. The strapping was also placed there, which was decorated with different sizes of tinned bronze rosettes (altogether 12) and a large strap end also with rosette motif. The strapping was folded. In general, horse harnesses are usually placed on the horse bones or close to them, so they rarely appear below or next to the head of the deceased.

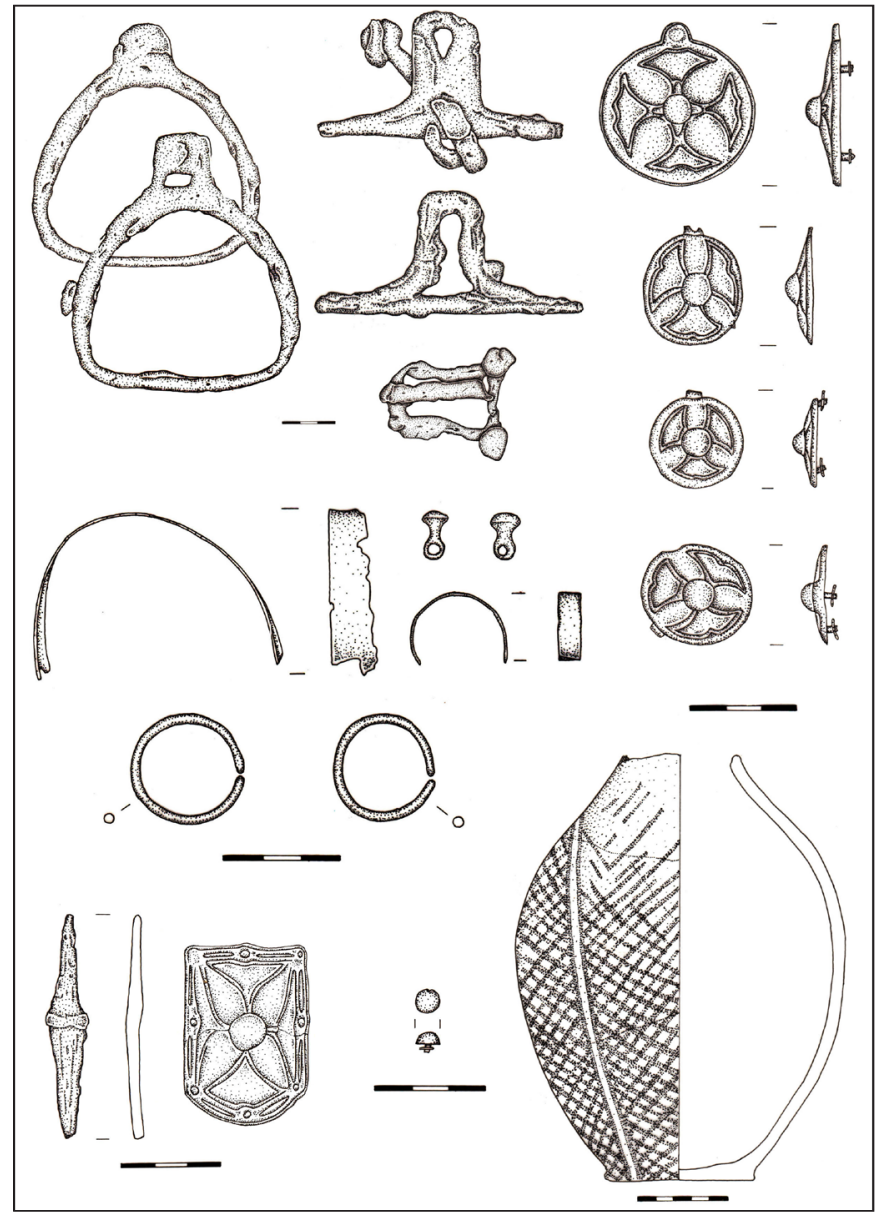

Fig. 6. Finds from the Hungarian Conquest Period grave at Tázlár-Templomhegy (Restoration and drawing: Gábor Barta) 
Horse harnesses decorated with rosettes represent a very characteristic group of finds from this period. This find type is specifically characteristic of the area between the Danube and Tisza rivers, but it is also one of the most common and widespread throughout the 10th century Carpathian Basin. Rosette mounts also appear east of the Carpathian Basin, where their number has doubled in the last few years. There is data on 13 mounts from eastern Europe to southwestern Siberia (GuLYÁs, GALLINA \& TürK 2019, 115).

This type of grave is not unique in the area of Kiskunhalas, since there was one similar female burial with a horse and horse harnesses with rosettes discovered each in Balotapuszta and Kiskunhalas-Dénes Marcell utca. Graves such as this appear throughout Hungary, but these people must have been part of a closed community, presumably members of a high-ranking group, who insisted on maintaining their traditions (band bracelets and band finger rings, ball buttons, boots with mounts, hardly any decoration on the clothing) (RÉvÉSz 2001, 58-64). The distribution of these graves perhaps corresponds with the settling of clans, as they appear 10-15 kilometres from each other (RÉvÉsz 2001, figs. 68, 42; LANGER 2017, figs 2-3).

The most interesting object from the burial at Tázlár is an elongated egg-shaped jug decorated with a red net pattern on a white base. The jug lay on its side next to the woman's left upper arm. This find is unique in the archaeological record of the Hungarian Conquest Period to this point. The closest analogy to this vessel can be found in Veliki Preslav, which was the capital of the First Bulgarian Empire. The vessel from Tázlár belongs to the Preslav type painted pottery category. Import finds from the territory of today's Bulgaria in the archaeological assemblage of the 10-11th century Carpathian Basin play a significant role in assessing relationships in the Balkans during this period. This ceramic find from Tázlár may open new avenues for analysing the relationship between the Carpathian Basin and Bulgaria in the 10th century, which so far has mainly been based on the stylistic analysis of metal objects (GULYÁs, GALLINA \& TÜRK 2019, 116).

According to recent knowledge, a group of common people settled and buried their dead in Tázlár in the 11th century, and they built a church sometime around the turn of the 12th century. This relatively large village church with a semi-circular apse was oriented in a NE-SW direction $(13.5 \times 9 \mathrm{~m})$. In the Árpád Period, a cemetery was established around the church of this community that had already been converted to Christianity. Life in the village, and thus the use of the cemetery, came to an end due to the Mongol invasion (for more detail, see: Gallina \& Gulyás 2018a, 44-49). In the Late Árpád Period village, we found several, special, post structured buildings (the posts held the infill of the walls or the side purlins) with special, horseshoe shaped furnaces that were burnt to a grey colour and were made of a hard/cemented raw material. Apart from these furnaces, or rather reheating forges, there were pieces of slag and the remains of a protective wall, due to which it can be assumed that industrial work (iron forging or perhaps copper smelting) was carried out in these workshops. Large, rectangular-shaped systems of ditches representing animal pens came to light in the flat peripheral area of the site, indicating extensive animal husbandry.

The Árpád Period cemetery, which surrounds the church, is situated to the east of the village. The majority of the graves were not W-E oriented as would be expected in this period, but SW-NE oriented, thus the head faced towards SW-S, adjusted to the position of the church. Of the two different orientation groups (W-E, SW-NE), the ones with SW-NE orientation are consistently the more recent graves. The older graves display some sort of row pattern. It is assumed that the earlier cemetery developed into a cemetery that surrounded the church (the so-called Gellértegyháza type), although this has yet to be proved.

In several graves, we observed a sidewall niche dug into the left (eastern) side of the grave. The dead were buried in an extended, supine position, in some cases in a burial shroud, or rarely in a coffin. The placement of the arms is characteristic of this period, both arms were situated alongside the body, but sometimes one of the arms was bent and placed on top of the body. Besides the customary way of laying the body, we found some irregular burials mainly in the case of older people - and double burials (a woman with a man, a mother with her new-born child). These people must have had difficult lives and worked hard, since pathological changes can be observed on the bones (broken arms, legs or ribs, hypertrophy at muscle attachment sites [enthuses], and rheumatic diseases). ${ }^{2}$ In the

The human remains were analysed by Antónia Marcsik and Zsolt Bernert. Among the skeletons analysed by Zsolt Bernert, several skulls showed symbolic trepanation. 
Árpád Period graves, there were only a few grave goods: bronze and silver, simple hair rings where one end was folded onto the other end, hair rings ending in an S-shape, hair rings with simple ends or with ribs, simple bronze and silver wire finger rings, and some silver obols from the 12th and 13th centuries. From one of the most recent graves prior to the Mongol invasion, a coin of Duke Bernhard of Carinthia from the 1220s was found.

The church of the village was surrounded by a tripartite ditch system, the purpose of which was not to enclose the cemetery but to protect the territory of the church. The outermost ditch encompasses an area of almost $110 \mathrm{~m}$, and its size is significant even today, with a width of $2.5 \mathrm{~m}$ and a depth of $1.5 \mathrm{~m}$ on the eroded surface. Several finds have come to light from the outermost ditch, including iron tools, an axe, a hoe, sickle, two spurs, so-called sheep shears, a belt buckle, a knife, an iron door mounting, the hoop from a wooden bucket, several medieval bricks, an intact millstone and a considerable number of larger burnt stone fragments, several among which are carved ashlars, indicating that the church met a violent end. At the bottom of the ditch, there was a burnt destruction layer with charcoal, possibly from the time of the Mongol invasions, and burnt wooden boards from a building had also fallen into the ditch. Since the ditch was more recent than any of the Árpád Period graves, it was probably dug just before the Mongol invasion, and it started filling up during the devastation.

In the middle ditch, we found the skeleton of an adult laying prone, who fell into the ditch or was thrown there without ceremony during an attack. In the same ditch, another male was excavated, similarly laying prone, but his hands were tied back. He was placed in the ditch in the decades following the Mongol invasion. The community was probably afraid of him even after his death, since he was oriented in the opposite direction, he was placed there with his face down and his hands were tied back, sickles were placed at his head to ward off evil magic, there was a knife at his leg, and stones from the Árpád Period church were also placed around him (Fig. 7).

Local people tried to hide their valuables during this turbulent time. Also in the middle ditch, an assemblage of ceramics came to light consisting of a cauldron used for cooking over an open fire, and eight different sizes of pots/cups. Perhaps food had been hidden in them.

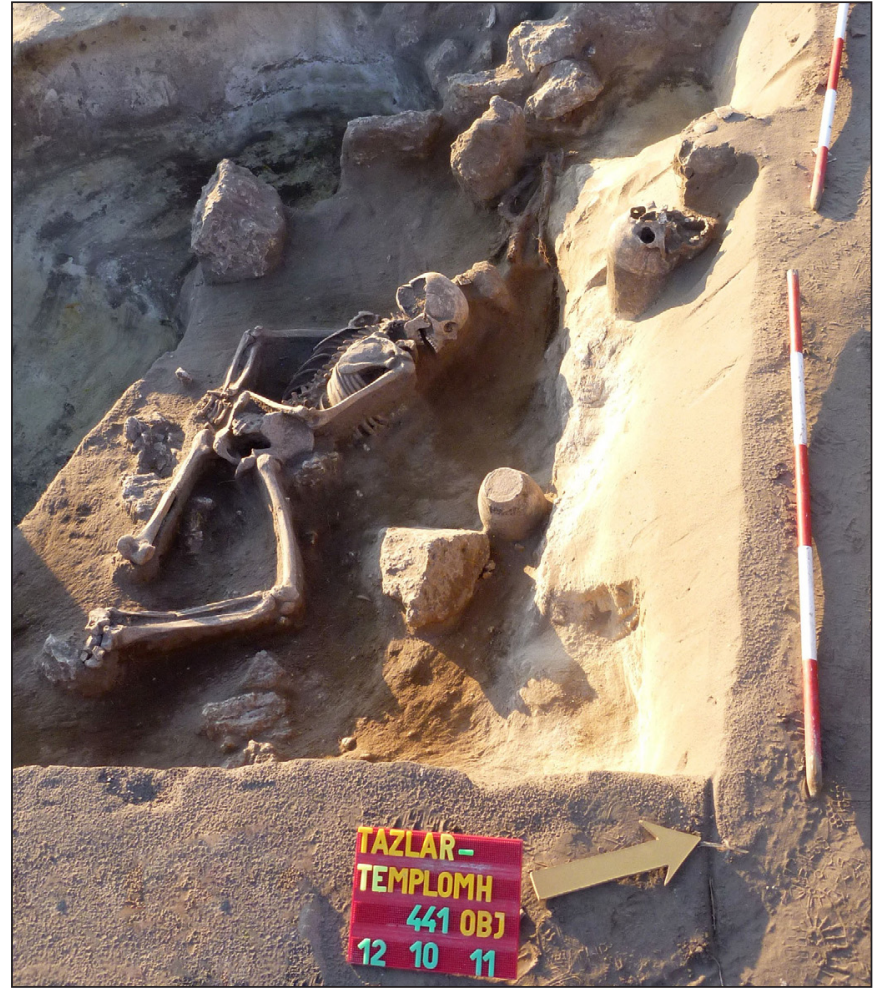

Fig. 7. A skeleton with his hands tied back in the middle ditch at Tázlár-Templomhegy (Photograph: Gyöngyi Gulyás)

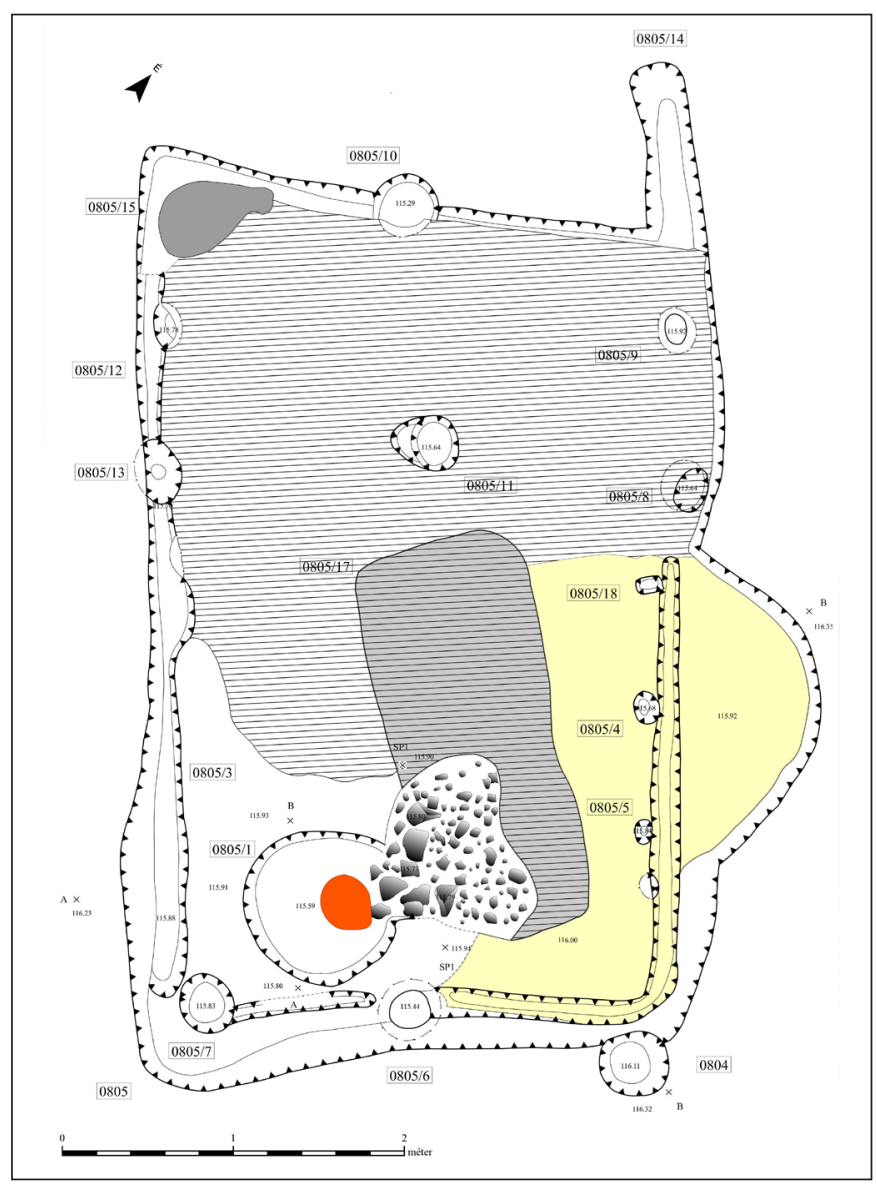

Fig. 8. Drawing of a 13th-14th century building at Tázlár-Templomhegy

(Drawing: Gyöngyi Gulyás, GIS: Archeoline Ltd.) 


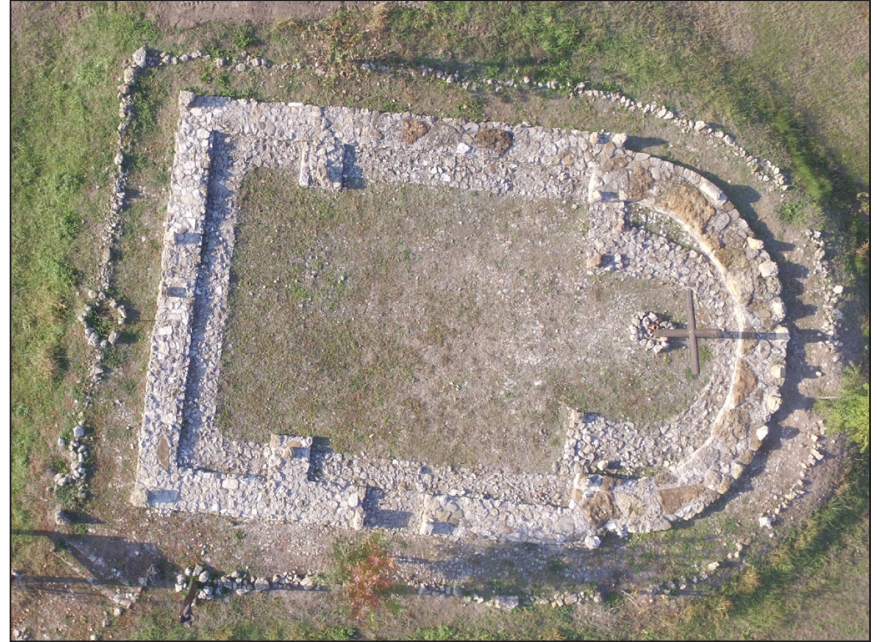

Fig. 9. Reconstruction of medieval churches in an aerial photograph at Tázlár-Templomhegy (Reconstruction: Máté Kurucz)

The outermost section of the tripartite ditch system was definitely dug during the Mongol invasion, and perhaps the middle section was also, but to no avail - the settlement was destroyed.

Similar multi-ditch defence systems (dual or tripartite) have also been observed at nearby sites, such as Szank, Kiskunfélegyháza, Kunfehértó, Szabadszállás, Dunavecse, Csengele, Tótkomlós and Orosháza-Szentetornya (Rosta 2018, 190, fig. 6).

In the decades following the Mongol invasion, returning Hungarians or new settlers, early Cumans, moved in and settled within the fortified area, within the outermost ditch, close to the church. Here they built their surprisingly advanced, large, semi-subterranean buildings with complex structures and filled in walls (Fig. 8). For example, the fire protector of a fireplace in one of the houses was presumably made

of the bricks of the church. Cumans settled in the area in greater numbers in the second half of the 13th century and the beginning of the 14th century. In the first half of the 15th century, the Cumans built a new church on the partially ruined old church, where some of the walls of the old church still stood. The orientation of the late medieval church was identical to the Árpád Period one and their walls aligned almost perfectly. The outer wall of the Árpád Period church became the inner wall of the later church. Its apse was changed, becoming wider and semi-circular (Fig. 9).

The late medieval graves of the 11th-16th century cemetery are usually oriented in a SW-NE direction. Wooden board coffins were generally used, and these were secured with nails and hinges. The placement of the arms of the corpses is varied and burial practices seem more diverse in this period - arms are bent and placed on the pelvis and chest more often. These practices are mainly characteristic of those who were buried inside the church. Burn marks and charcoal remains as signs of purification could be observed in about 30 Árpád Period and late medieval graves.

In this later period, the bones from Árpád Period graves were collected and were reburied in an ossuary. Late medieval graves also had only a few grave goods, such as so-called Parisian clasps, bronze and iron belt buckles, bipartite cloth fasteners, signet rings with double cross and bird depictions, dress fittings, pressed disc-shaped plates, and headdress ornaments. Characteristic finds of one or two Cuman graves were a beaded sabretache with an iron knife and a silver clasp, a plate-metal spherical earring and ornamented belt mountings.

In some graves, sharp iron objects (arrowheads, sickles) appeared, which can be understood as survivals of pagan traditions. These objects were used to ward off evil magic. We established an archaeological memorial park at the excavated area in 2014, and this work still continues. As a part of this, we have reconstructed the wall remains of the two churches and the ditch system that has been excavated. We have tried to make the past and the efforts of our predecessors visible through this monument for the edification of today's generations.

\section{EARLY MODERN PERIOD GLASSMAKING WORKSHOP AT PUSZTABÁNYA}

Glassmaking was once a flourishing industry in Hungary, which mainly developed from the end of the 17th century, after the Ottomans had been driven out of Hungary. In this period, window glass and so-called 'container glass' or 'peasant glass' for everyday use became widespread in the different social groups. In the eastern part of the Mecsek Mountains, four workshops made glass from the end of the 17th century until the beginning of the 19th century. The last of these was the one at Pusztabánya, which operated from 1784 to 1805 (for more details see LANG 2008). There have been excavations and glass furnace reconstructions at this industrial archaeological site in recent decades under the leadership of Gábor Kárpáti, János Jegenyés 
(glass artist) and Ádám Lang Jr. (historian). Following in their steps, we had an opportunity to excavate a complete glassmaking workshop between 2016 and 2018 and to reconstruct its operational principles (Gallina \& GulYás 2018b, 64-68). Pazirik Ltd. made a short movie and $3 \mathrm{D}$ reconstruction on the excavation and reconstruction work in 2019 under the guidance of Zsolt Gallina (PAZIRIK Ltd. 2019).

The glassmaking workshop at Pusztabánya is uniquely well preserved considering the conditions of similar buildings in Hungary and Western Europe. This may be due to the fact that its occupants left it as it was and did not demolish it. The full length of the building is 37-38 $\mathrm{m}$, its width is $11-15 \mathrm{~m}$, and despite its large size there are no signs of supports within the building (Fig. 10).

In the so-called glassworks, several work processes were performed: firewood was dried, quartz sand was melted, and ash and lime were added to make melted glass. This is where glassblowing and production took place, as well as the drying and cooling of the final products. Moulds were also kept here, as were the clay trays used for cooling, the various tools, and perhaps the final products.

The well-preserved so-called double furnace (melting and annealing) is situated in the central part of the workshop. Around this, we also found the hard, compacted former walking surface.

North of the double furnace, there was an almost $5 \mathrm{~m}$ long, rectangular structure with a stone exterior and brick interior that presumably was a wood drying kiln. At the western side of the glassworks we excavated a double chimney furnace system. This furnace protruded significantly from the wall of the workshop. Its exterior was made of stone and its interior of brick, and its bottom was also made of brick. Presumably, this furnace was used for plate glass casting, calcination and production of colorants. Around the kilns

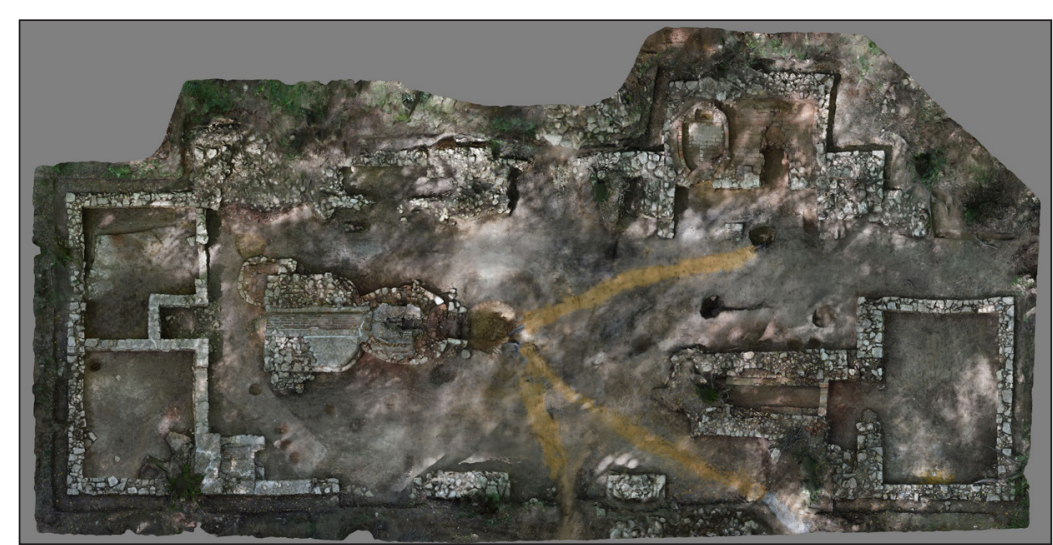

Fig. 10. Aerial photograph of the glassmaking workshop at Hosszúhetény-Pusztabánya (Reconstruction: Pazirik Ltd.)
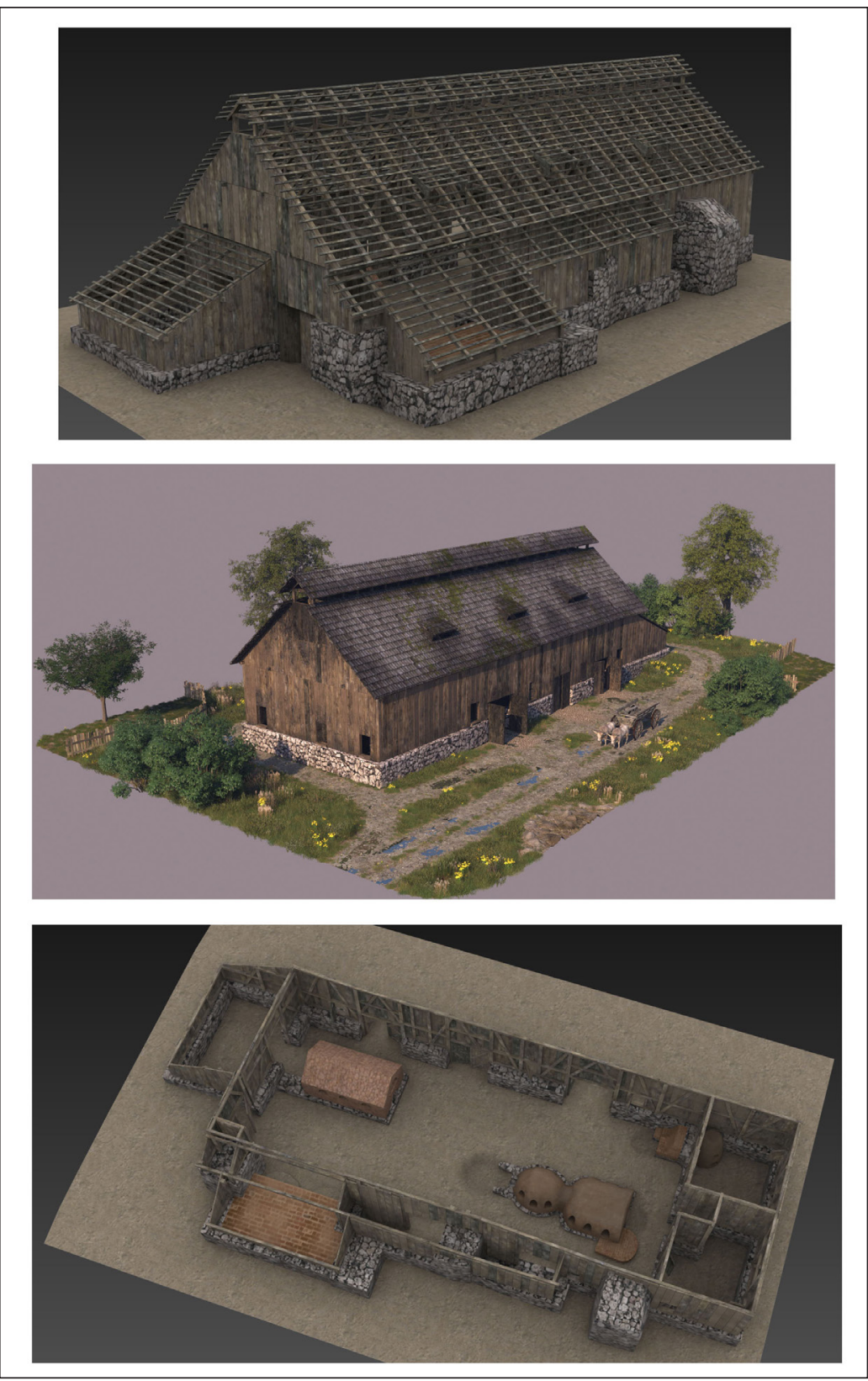

Fig. 11. 3D reconstruction of the glassmaking workshop at HosszúhetényPusztabánya, the structure of the reconstructed building and its interior (Reconstruction: Pazirik Ltd.) 
and furnaces there were several smaller pits, serving areas, find concentrations, and burnt areas, all of which were the scenes of former work phases, indicating the sophisticated stages of production.

Chambers were discovered at the northern and southern ends of the building. The one at the northern end may have been used for storing final products or wood. The southwestern chamber may have been used for storing chemicals, poisons and lime. The southeastern chamber, which was heated during the winter with a tiled stove, may have been the living quarters of the master glassmaker, who kept the equipment for glass blowing here such as mould fragments, tools (shears) and clay cylinders.

This workshop that operated for just over two decades had buttresses supporting the wall on its side facing the hill, and there are several signs that the workshop was rebuilt at least once.

The eastern wall had three entrances, each almost $3 \mathrm{~m}$ wide, and their sills were paved with flat stones. The northern side of the workshop also had an entrance, with a base that steeply slopes towards the building (Fig. 11).

During the excavation, a very large amount of glass came to light, which included fragments of plate glass and so-called green peasant glass and forest glass. We found some unique finds from which it is clear that it was not only mass-produced glass objects that were made here, but also unique and expensive glass products. These unique finds are fragments of two transparent glass objects with embossed lilies and a jug with a blue coloured rim. Besides these, we also found stone and clay objects used for glass production (fragments of ceramic crucibles, stone mixing bowls, ceramic trays/sheets used for cooling, clay cylinders, and glass tubes) (Fig. 12). Besides finds associated with glass production, some personal items of the workers also came to light, such as a smoking pipe with a metal lid, a silver belt buckle, iron knives, a ring, iron scissors, a file, fragments of glazed and unglazed bowls and several coins dated between 1761 and 1800 .

We know that this glassmaking site did not become a real village. The southern German and Czech-Moravian glassmakers mainly came from Kisújbánya, where an earlier glassmaking workshop is situated. Surface finds in the wider area around the workshop and LIDAR images indicate that the existence of several further buildings can be presumed (the house of the master glassmaker, a sawmill, a mill for grinding gravel, a glass warehouse, and workshops for the preparation of raw materials). It is certain that Pusztabánya (Vitriaria) was the last glassmaking workshop that operated in the eastern Mecsek Mountains, which was quickly depopulated. After it was abandoned, itinerant blacksmiths and/or Romany occupied it because its walls were still standing. The workshop burnt down after it was abandoned or after the itinerant people left. After this, the ruins quickly became overgrown by the forest, which has also preserved it.

After the excavation, we began the conservation of the ruins and the plan for its reconstruction, since the building is uniquely well preserved compared to other European sites and can be interpreted and presented. We hope that it can truly be woken up from its slumber of several hundred years and once again become a gem of the Mecsek Mountains, as this once was the largest industrial site in Baranya County.

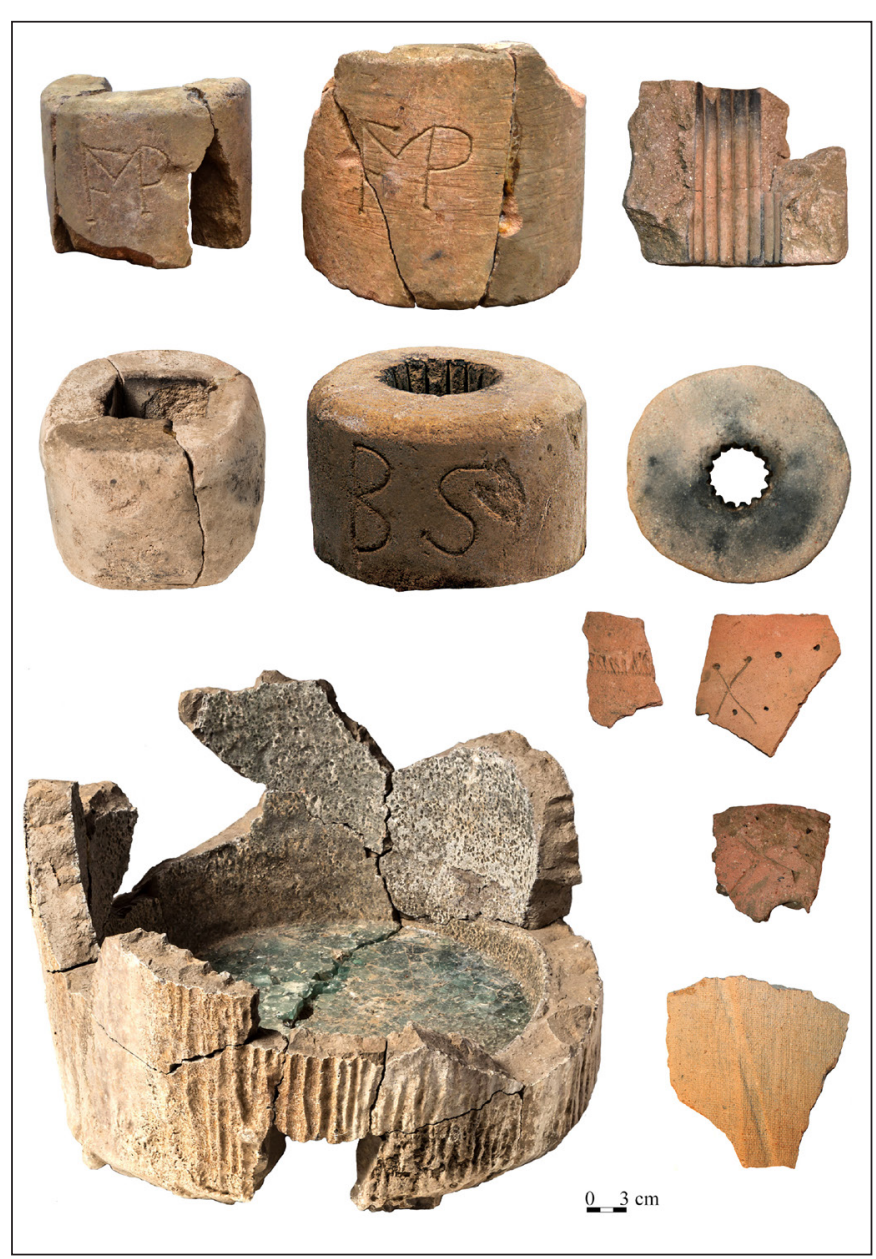

Fig. 12. Finds from the glassmaking workshop at Hosszúhetény-Pusztabánya (Restoration: Róbert Móricz, Photographs: Róbert Móricz and Gyöngyi Gulyás) 
Zsolt Gallina - Gyöngyi Gulyás • Churches, Graves and a Glassmaking Workshop

REFERENCES CITED

F. Bodnár, K. (1988). Kolostor a kiskertben [Monastery in the backyard]. Múzeumi Mozaikok 1988 (2), $35-36$.

Gallina, Zs. \& Gulyás, Gy. (2018a). Homokba temetett falvak és templomok. A tatárjárás korának emlékei a Kiskunságban [Villages and churches buried in the sand. Remnants from the period of the Mongol Invasion in Lesser Cumania]. Határtalan Régészet 3 (1), 44-49.

Gallina, Zs. \& Gulyás, Gy. (2018b). „Pusztabánya hol régenten övegbánya volt, egyes maradványa még látható". Az utolsó mecseki üveghuta története [“There used to be a glass workhop at Pusztabánya, some remains are still to be seen". The story of the last glass workshop in the Mecsek Mountains]. Határtalan Régészet 3 (4), 64-68.

Gulyás, Gy., Gallina, Zs. \& Türk, A. (2019). Újabb régészeti adatok a Duna-Tisza köze honfoglalás kori településtörténetéhez és a 10. századi bolgár-magyar kapcsolatok kérdéséhez egy tázlári sír kapcsán [New data on the settlement history of the Danube-Tisza Interfluve region in the Hungarian Conquest Period, and on the Bulgarian-Hungarian relations in the 10th century, in connection with a grave unearthed in Tázlár]. In Sudár B. \& Türk A. (eds.), „Hadak útján.” A népvándorláskor fiatal kutatóinak XXIX. konferenciája. Absztraktkötet (pp. 115-121). Budapest, 2019.

Lang, A. (2008). Üveghuták a Kelet-Mecsekben [Glass workshops in the eastern Mecsek Mountains]. Pécs.

Langer, D. (2017). A honfoglalás kori rozettás lószerszámveretek keleti kapcsolatrendszere [Eastern connections of the Hungarian Conquest period horse harness mounts decorated with rosettes]. Paper submitted to the National Scientific Students' Associations Conference. Pécs.

Pazirik Ltd. (2019). Az utolsó mecseki üveghuta története [The history of the last glass workshop in the Mecsek Mountains]. https://www.youtube.com/watch?v=1I3vss6SuIM. Last accessed: Nov. 27, 2019.

Révész, L. (2001). Aranyszántás Balotán. Gazdag honfoglalás kori női sírok Kiskunhalas környékén [Golden ploughland in Balota. Rich female graves from the period of the Hungarian Conquest around Kiskunhalas]. Budapest-Kiskunhalas: Magyar Nemzeti Múzeum.

Rosta, Sz. (2018). Egy új lehetőség kapujában - tatárjáráskori védmüvek a Kiskunságban. In D. Mérai, Á. Drosztmér, K. Lyublyanovics, J. Rasson, Zs. P. Reed, A. Vadas, \& Cs. Zatykó (eds.), Genius loci. Laszlovszky 60 (pp. 186-192). Budapest: Archaeolingua. 